\title{
The White Power Movement's Populist Connection to the Tea Party Movement in the United States
}

\author{
By Betty A. Dobratz* \\ Lisa K. Waldner
}

There has been considerable discussion about the extent of racist ideology in the Tea Party Movement (TPM). Although we consider this to be an important issue, we focus on how the ideological framings of the White Power Movement (WPM) and the TPM are similar, especially in respect to right-wing populism. We examine particularly the producerism, scapegoating, and conspiracism of populism. We analyze our own WP data collected in the 1990s and early 2000s and compare it with the social science findings on the TPM. Although there are certain differences, there are significant similarities that provide support not only for a race frame but for other populist bridging frames between the two movements which we suggest increases the likelihood they interact and recruit each other.

Keywords: Conspiracism, Populism, Producerism, Tea Party Movement, White Power Movement.

\section{Introduction}

Drawing on data collected prior to the beginning of the TPM, we show how the framings of WPM ideology have significant populist elements that would make the TPM an attractive venue to join and to potentially recruit supporters. A frequently debated question about the TPM is its racist connections with the WPM. We briefly consider the racism issue but concentrate on other ideological connections that exist because of their populist views on producerism, scapegoating, and conspiracism. We argue that the WPM and the TPM share several common frames that increase their appeal to each other.

\section{The Framing Perspective}

The ideology or belief systems of social movements are continually being framed or constructed, interpreted and reinterpreted. Such frames simplify and condense what is going on in the real world as individuals strive to understand what is occurring. Snow et al. (1986) identified four types of framing alignment processes. Frame amplification involves the focusing, clarifying, or

\footnotetext{
* Iowa State University, Sociology Department, USA.

${ }^{\dagger}$ University of St. Thomas, Sociology and Criminal Justice, USA.
} 
invigorating of a frame by stressing values such as justice and equality. Frame extension happens when the boundaries of a framework are extended to include interests of potential movement supporters. Frame transformation refers to modifying or redefining ideology or values so that they are more in line with those of the broader society. Frame bridging occurs when two or more ideologically similar but structurally unconnected frames are linked together.

\section{The Framing of Race}

Issues surrounding race are important in both movements. Simi and Futrell (2010) point out how White Power (WP) organizations reframe their front stage message to make it more acceptable to the public by using appeals to cultural pluralism and utilizing a victim frame. Berbrier (2000) employs a constructionist perspective to identify five separate victim themes: 1 . oppressed victims of discrimination; 2 . abrogation of whites' rights; 3 . stigmatization and exclusion from racial pride; 4. deflation of self-esteem, and 5. threatened survival of the white race. Berbrier (1998) suggests WP advocates search for strategies to make their beliefs more culturally resonant because especially since the 1960s expressions of blatant racism have become less acceptable in society. Framings include expressions of love of one's race rather than hatred of another race and the development of pride in and preservation of one's own white heritage in an attempt to transform the stigma of white supremacy. This reframing process includes amplification or clarifying of one's position but more profoundly involves an attempt to transform their views to make them more acceptable to the public.

Members of the TPM also see themselves as victims. For example they pay high taxes for a welfare system that they feel often supports lazy minorities. Many in the TPM claim that they are not racist, but some researchers note that their racism is a subtle or color-blind type (Skocpol and Williamson 2012, Street and DiMaggio 2011, Burke 2015), Some emphasize how their racism brings them closer to right-wing extremism such as Hewitt's (2014:307) proclamation that "Currently, the TPM appears to represent the extreme right" and Parker and Barreto's (2013:188) assessment that "the TPM is beginning to look more and more like the contemporary representation of the Far Right. Like the Klan".

\section{Methodology}

To understand the WPM, we developed an interview schedule that included open and closed-ended questions about the WP respondents' social characteristics, their attitudes about race, religion, gender, and politics, and their views of the movement and the future. From 1992-2002 one or both of us attended numerous events sponsored by WP leaders. Those events included twelve Klan ones, six World or Youth Conferences at Aryan Nations, five held 
by the National Socialist Movement, and several others by miscellaneous or independent groups. Some of the interviews at these events were conducted with Stephanie Shanks Meile (see Dobratz and Shanks-Meile 1997) and others were also conducted by telephone. At the events we did not have time to interview all attendees and therefore asked some to complete questionnaires that were essentially the same as the interview schedule although selfadministered. In addition we either emailed or sent individuals questionnaires through the United States Postal Service. Individuals typically returned them via email or in the stamped envelope we provided them. The interviews were transcribed by secretarial staff after they were conducted. One hundred fiftynine interviews and questionnaires were coded using the Statistical Package for the Social Sciences (SPSS) Version 20, a quantitative data analysis software package. Once data were coded, various statistical procedures such as frequencies and cross tabulations of the variables were performed. For this article we used the chart option to create a pie chart based on the frequencies of answers to the question about which group or groups (the rich, the middle class, the working class, the poor) respondents thought were more likely to be attracted to their white power organization.

The ninety-eight transcribed interviews and an additional ten transcribed rally speeches were imported to NVivo, a qualitative data analysis software package designed to help organize, analyze, and provide insights from the qualitative data. (The speeches were not included in the quantitative SPSS data files). Using its search and query function, we identified all paragraphs that contained selected key terms (e.g., working class, conspiracy, elite, New World Order, and Jew) that were used by the interviewees in their responses to our questions. The statements and specific quotations of white power supporters used in this article were identified through such NVivo searches. We used pseudonyms for the names of interviewees rather than their real or movement names in this article.

To make comparisons with the TPM, we draw on previously published social scientific analyses of that movement. We focus on those individuals who are at the local or grass roots level of support for the TPM or those who indicate support for the TPM in public opinion surveys rather than those who are at the top echelons directing candidate selection for elections.

\section{The Populist Connection}

We explore how the characteristics of right-wing populism are similar in both movements thus offering bases for frame extensions and bridging among their supporters. Populism as an ideology comes in various forms including from the left, the center, and the right. We focus on right-wing populism that Canovan (1992: 2) suggested should be "understood as an appeal to 'the people' against both the established structure of power and the dominant ideas and values". Populists see themselves as representatives of legitimate power because they believe they speak for "the people" (Canovan 1992: 10) or 
"'ordinary decent people', whose interests and opinions are (they claim) regularly overridden by arrogant elites, corrupt politicians and strident minorities". Further, the democratic pretensions of populism suggest a complex relationship between democracy and populism since populists seek to mobilize the electorate to bring about significant changes in the political system.

Kazin (1998:1) views populism as "A language whose speakers conceive of ordinary people as a noble assemblage not bounded narrowly by class, view their elite opponents as self-serving and undemocratic and seek to mobilize the former against the latter". Populist language has been "rooted in the gap between American ideals and those institutions and authorities whose performance betrays them" (Kazin 1998: 289). He believed it wasn't until after 1945 that appeal to the people became more "detestable" including "fear of the black and immigrant poor, a belief in conspiracies, loyalty to America and to God used as a club to beat one's rivals" (Kazin 1998: 6). We draw especially on Berlet and Lyons (2000: 6-13) identification of producerism, scapegoating, and conspiracism as fundamental concepts of right-wing populism.

\section{Producerism}

Berlet and Lyons (2000: 6) define producerism as "a doctrine that champions the so-called producers in society against both 'unproductive' elites and subordinate groups defined as lazy or immoral". In their chapter entitled "Robbing the Productivity Train" Leicht and Fitzgerald (2014) document that since the 1980s worker productivity has risen but wages have not. For those in the middle of the class hierarchy the authors argued "prosperity in the late twentieth and early twenty-first centuries is an illusion" (Leicht and Fitzgerald 2014: 4).

$W P M$

As part of our study, we asked WPM supporters the following question: "Would you say your organization appeals more to those who are rich, middleclass, working-class, or poor?" Figure 1 displays our results which show that $28.30 \%(\mathrm{~N}=45)$ of the 159 supporters coded in SPSS identified their members solely as workers and a total of $80.5 \%(\mathrm{~N}=128)$ of the responses included the working class. The category that included all four classes/groups was second most frequent with $22.64 \%(\mathrm{~N}=36)$ identifying all the groups. About $46 \%$ $(\mathrm{N}=73)$ mentioned the middle class in one form or another. $10 \%(\mathrm{~N}=16)$ did not answer the question and if they are dropped from the totals then the working class is identified separately or with other groups $90.2 \%$ of the time. 
Figure 1. Pie Chart: White Power Movement Organization Appeals to What Social Class

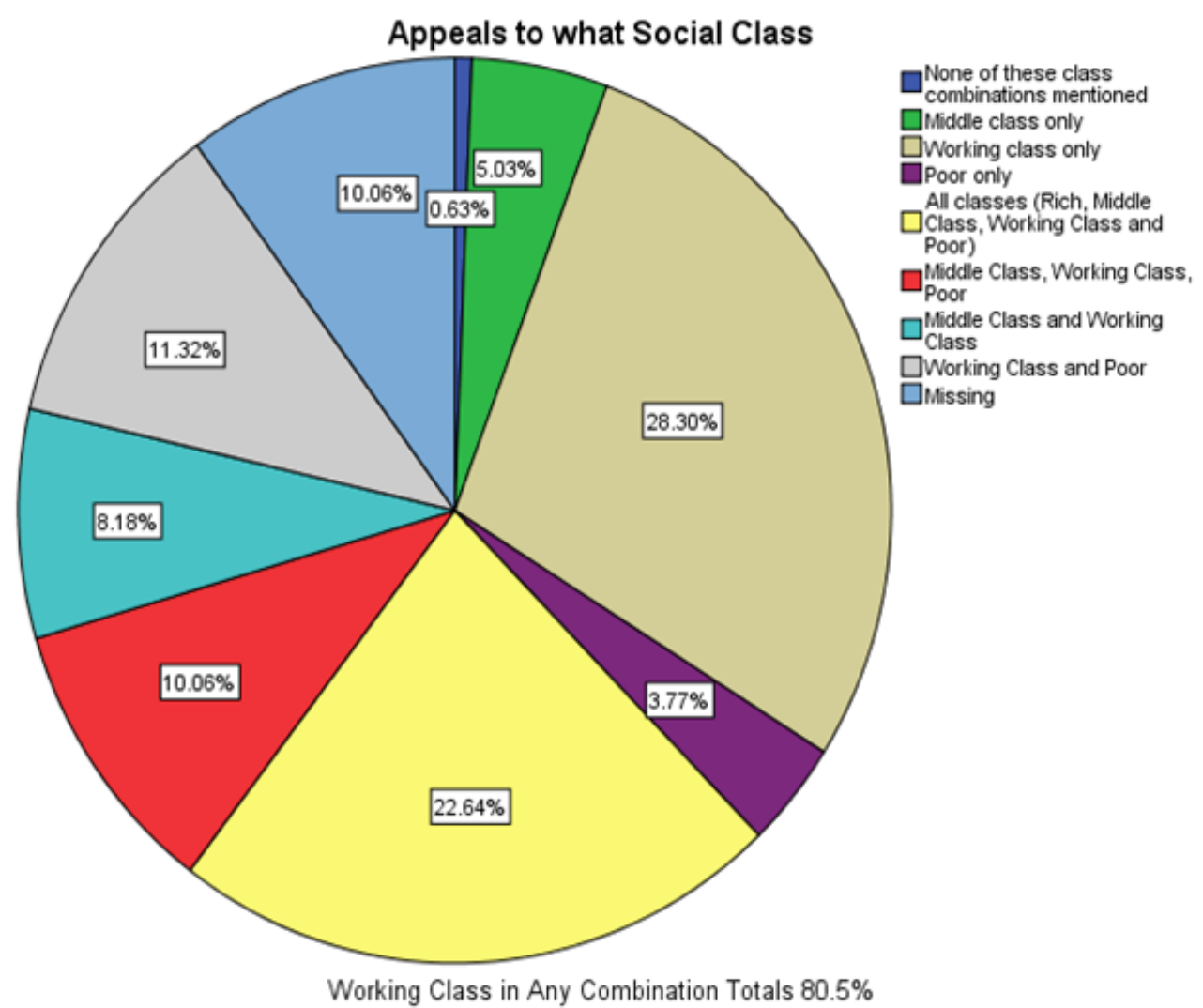

The NVivo searches provided numerous qualitative descriptions of who supported the movement and particularly focused on those with working class blue collar occupations such as David's assessment: "We all are working class...We're all carpenters--we're all brick layers--we're all mechanics--we tend to have callouses--we tend to smell". Others acknowledged some overlap with the middle class like Charles who stated that "Working Class. Lower, middle, that's it. They keep us at a lower level, you know".

Some WP supporters praised the working class as the backbone of the movement. For example, one leader Ralph commented: "Those are the main ones that really stand up and hold us together, cause they're people who struggle every day that 40 years ago they would have a better life if it wasn't for what's happening today in this country". Many supporters recognized how the economic situation has negatively impacted those in the movement.

The producerist ideology not only praises those who work hard but tends to negatively label many at the top and the bottom. Robert explained that some in the movement tend to believe "there goes... a lazy man simply because he is rich" but he like some others recognized that some are "well off individuals with a white collar or no collar who work hard". This would include inventors 
like Edison and Bell who should enjoy the benefits of their own labor. He adds though "oppressive wealth and profiteering by idle people who simply live off the sweat of others and who do not work such as people in the wholesale trade to a great extent or people in the stock market or manipulation of currency and those types... will be severely restricted and in many cases eliminated altogether so there will be true social justice in society".

The rich and powerful capitalists are criticized especially by the national socialists in the movement. For example Tim pointed out how "the original founders of corporations and companies... wanted to produce a product...some excellent products were made". But as capitalism had evolved, he found "capitalism...is causing destruction everywhere" and concludes capitalists "take people from the late teens and basically by the time you're 40 , you're worn out... and throw them away". The rich are also typically perceived as unconcerned about racial issues. Mike stated: "The rich are participating in the very exploitation that the Jews have used to keep white people down. The rich do not care about protecting our race because they are too wealthy and secure to see the problem. They send their kids to private school so they don't see the destruction caused by integration".

Some in the movement like Jeff recognize that certain people are worthy of social services but others aren't: "If people are on welfare because they need it, that's one thing - but people ... on welfare because they're just plain lazy - no, we don't appeal to people like that because we are working class". Often WP supporters characterized the undeserving as black and used common stereotypes. For example Morris stated: "It's ok for these Niggers to go out and breed like flies...have ten children and different fathers-not collecting a dime from either one or any of them. But sit there on welfare and smoke crack and buy new Cadillacs... and we have to pay that. The hardworking man like me...". Another, Cecil complained: "Why is that black guy up in front of the line ahead of me when I've been working all my life donating to pay for his welfare?" The concern of having to pay for someone who was able to work but unwilling was a strong theme in our interviews.

\section{$T P M$}

TPM supporters are concerned about "the people". A 2010 US survey of by World Public Opinion found that 55\% of those who supported the TP selected as most important that government "is not following the will of the people" while $31 \%$ identified as most important the government "becoming too big" (Kull 2010). This supports that TP supporters are likely to see themselves as part of "the people".

Scher and Berlet (2014:109) point out that what motivates much of TPM populist producerist rhetoric is "the claim that hard-working productive middle-class citizens are being squeezed in an economic vise-from above by high government taxes, onerous regulations, and monetary politics set by greedy bankers, and from below by lazy, sinful, and subversive parasites". Furthermore Berlet (2012a) argues these grass roots activists "routinely 
condemn the financial manipulators, 'banksters',... 'parasitic' corporate elites". Burke (2015) points out that while many in the TPM favor free trade and free enterprise, they don't necessarily perceive NAFTA as a fair trade agreement. She observed panelists at a TPM convention use the term "capitalist pigs" and be critical of corporations. Also many did not support the bailouts of the banks.

Looking at those on the bottom of the hierarchy, Skocpol and Williamson (2012: 77) point out that Tea Partiers fear budget deficits will lead to tax hikes that result in people like them paying more "for social spending that benefits undeserving freeloaders". Although Tea Partiers are frequently identified as middle class and having higher than average income (Street and DiMaggio 2011, Scher and Berlet 2014), Scher and Berlet (2014), Skocpol and Williamson (2012), and Burke (2015) describe how Tea Partiers have negatively experienced the effects of the Great Recession. They note the Tea Partiers' concerns about the viability of their retirement and the future for their children. Tea Partiers tended to display some of the most negative views of the economy and felt that the rules to achieve the American Dream were no longer working (Skocpol and Williamson 2012: 30).

\section{Scapegoating}

Berlet and Lyons (2006:8) define scapegoating as "the social process whereby the hostility and grievances of an angry, frustrated group are directed away from the real causes of a social problem onto a target group demonized as malevolent wrongdoers". Typically this process involves negative stereotyping and those who scapegoat develop a greater sense of unity among themselves. Demonization occurs and includes "an ideological process in which targeted individuals or groups are placed outside the circle of wholesome mainstream society through political propaganda and age-old prejudice" (Berlet and Lyons 2006: 7).

\section{$W P M$}

As we have already seen in the context of welfare, Blacks have been subject to scapegoating as they are blamed for higher taxes that hard-working Whites have had to pay. Supporters of the WPM also particularly blame the Jews whom they see as very powerful, sometimes all powerful. For example a speaker at a Ku Klux Klan rally in 1994 condemned the Jews for dominating the government and defined the often used expression of Zionist Occupational Government (ZOG) for the audience: "I'll explain ZOG. We'll start with the Z. Zionist, is someone who will sacrifice any person, anything, or any nation for the greater good of Israel. Occupational means possession by force rather than voluntary agreement. And the last one is government, total population. In other words, people with ??? [inaudible] alliance to Israel rather than America, have seized power here and now rule us. Look who controls the banking system. 
Look who controls our media and Hollywood. The Jews. The Jews want to destroy Christianity and destroy the white race by race-mixing".

Andrew scapegoated the Jews while he was explaining the meaning of WP: "I think White Power... means the ability for our race to govern ourselves... not have alien interests--namely the Jewish interests--control the thoughts and minds of our people, especially the young... I think the Jews... realize that we are their main opposition... they monopolize the media and then ultimately our thoughts as white people... We're only told what... the Jews or Zogist...want us to hear". We will detail more about the power of the Jews under the topic of conspiracism.

Scapegoating the government either in general or specific officials occurs frequently. A frequent theme is that government favors things that harm the white race. For example Rick claims "This government pushing more for abortion" and it is mainly white babies that are aborted and that government allows race-mixing and homosexuality. Carrie states "look at what government has given to them [Blacks, Indian, Arab, Vietnamese named earlier]... business... homes...car... food stamps. They don't have to pay for nothing. But yet, me, a natural-born citizen whose forefathers fought for this countrygets nothing." While the government is seen as giving things away, concern is also expressed about taking their guns away. Others express concern about government facilitating terrorism. For example, Hal said "The US government... has been behind a great deal of the terrorism of the last 10-15 years like Oklahoma City and the terrorism in New York there with the Arabs. They've had their informants in place. They've been encouraging that. Because every time that they can get a terrorist act going, then they're able to extend the power of their leviathan over all of us".

Clinton, as President of the US, was frequently singled out. One speaker at an American Knights rally in Portage IN claimed he felt sorry for America because it was being demoralized by Clinton who belonged to the Communist Party and was using taxpayer money to cover up his two illegitimate children, one with a black prostitute. Another labelled Clinton a "skirt-chaser". Jim strategized: "I was telling all my friends-vote for Clinton-he's going to screw everything up and the movement will grow. That's exactly what happened". Several others in the movement too believe that as things get worse, more people will be attracted to the WPM.

Matt managed to negatively label Blacks, Jews, and the Clinton administration at his speech during a Klan rally in Rockford, IL. He maintained: "The Jewish media and the criminals of the Clinton administration continue to promote ...violence... Negroes are out of control in the country and our image as a great nation has been reduced to that of a third world nation... the Jew puts his money into government. This way he can exploit his victims again and again. He gets closer to men in charge of decisions. He begs for privileges which he always gets from the men who are always in need of money. Like the Clinton administration". To him, the government whether in general or controlled by Jews or led by President Clinton have created severe problems for its white citizens. 


\section{The TPM}

Berlet (2012b:567) summarizes the scapegoating done by Tea Partiers: "When TPM activists hold government spending hostage they see themselves as patriots protecting America from financial ruin at the hands of tax-andspend liberals in the Democratic Party. Congressional Town Halls ring with polemics charging that President Barack Obama is greasing a slippery slope of big government collectivism that will slurry the nation into an immoral cesspit of totalitarian tyranny. Signs appear at rallies comparing Obama to both Hitler and Stalin".

According to an April 2010 poll of 1,580 adults that included an oversample of 881 TPM supporters, $92 \%$ of the TPM supporters and $52 \%$ of all respondents believed Obama's policies were moving the country more toward socialism (Zernike 2010:211). Obama's bailout of automobile manufacturers and his push for health care reform were particular targets for a "politics of demonization" (Scher and Berlet 2014:113).

Parker and Barreto (2013) found racism a significant predictor in TPM support. Street and DiMaggio (2011: 83) found 73\% of Tea Party Supporters, $56 \%$ of all whites, and $33 \%$ of TP opponents agreed with the statement "It's really a matter of some people not trying hard enough; if blacks would only try harder, they could be just as well off as whites". Earlier we mentioned the racism of the TPM and we suggest that can easily result in scapegoating especially of blacks.

\section{Conspiracism}

Conspiracy theories have historically been part of American politics. Conspiracism is a type of scapegoating that frames the enemy as part of a vast insidious plot against the common good (Berlet and Lyons 2000:9). Barkun (1997) suggests that when conspiracies are taken seriously, people tend to trust authorities less.

\section{$W P M$}

Part of the demonization of ZOG has resulted in the conspiratorial position that the federal government is trying to destroy the Aryan race and heritage (Barkun 1997:111). Kaplan (2000) suggests that to the WPM ZOG represents the successful triumph of Jewish conspiracy not only in the US but throughout the world. One movement leader Mike summarized the beliefs of the movement nicely: "The Jews are essentially the root of all evil in modern society. They are involved in a conspiracy and a plan to gather as much governmental power, economic power, societal power, religious power, as they can for their own aims and as such we consider that evil because it opposes diabolically, diametrically the interest of our people". 
The Protocols of the Elders of Zion (The Protocols) is an anti-Semitic fabrication that described a Jewish plot to dominate the world. It likely was written in the early 1900s and first published in Russia. Kaplan (2000) considered it "the most important anti-Semitic document of the modern era".

WPM supporters believe The Protocols predicted a number of negative events for the white race that many believed even though the document may be a fake. One argued for its relevance stating "the Jews...keep trying so hard to prove that the Elders of Zion are not true. I won't dispute it. Ok, they're fake. Whoever wrote them up in $1911 \ldots$ was the greatest genius that ever lived because now you got the Jews doing all the things that they...said they were going to do... Who are all the sports promoters? They're Jewish. Who are the TV promoters? Jewish. ... -they're promoting the blacks. Because now the blacks are the kids' heroes". Thus The Protocols are cited to justify a variety of strategies Jews use to destroy the White race.

Another important conspiracy has been referred to either as The New World Order (NWO) or the One World Order (OWO). Although the expression has been used earlier, George Bush popularized the term during the Gulf War to discuss a newly revised collective security system (Barkun 1997). However some on the right believe it represented a conspiratorial plot by secret groups for world domination (Barkun 2003). Mark defined the NWO as "the Jew world order. It's the United Nations, the federal government and all the facilities that go along with it...one of the most evil things that's ever happened on the face of this earth. It only equals the destruction of the white race". Hal suggested "It's to make the world safe for Coca Cola to create a gigantic market for...capitalism and to destroy everybody's heritage and everybody's pride in place and family because once the white race has been eliminated, this New World Order will do the same thing to black people and to Asian people.... Because the only ones who are allowed to have a sense of racial purity...is Judaism and Zionism". Finally, Walter suggested "no one escapes this lovely New World Order".

One form of the NWO conspiracy theory revolves around the Bilderbergers founded in 1952 and composed of European and American political and business leaders who developed common transatlantic policies in closed meetings. Drawing on some of the same members, another is the Trilateral Commission created under the leadership of David Rockefeller. It included some of the Bilderberg group but also government, academic and business institutions (Barkun 2003). Bob, speaking at an American Knights Rally in 1996 explained: "The Jews are in control of the money. David Rockefeller... president and chairman of the board of Chase Manhattan Bank...is a member of the Tri-Lateralist. ... They are a small group of men controlling a large sum of money. Eighty percent of the world currency controlled by a few Jews. That's what we're fighting against... We need to put the power back into the white Christian American people". 


\section{$T P M$}

Conspiracy theories are also particularly strong within the TPM, especially ones about creeping socialism and "an apocalyptic vision of Barack Obama as the Antichrist, an agent of Satan, coming disguised as a 'man of peace'" (Scher and Berlet 2014:113). Parker and Barreto (2013) examined forty-two TPM websites for two years and compared their results with their examination of National Review Online (NRO) which they argue is illustrative of mainstream "responsible" conservatism. They found $33 \%$ of TPM content (the highest single percentage) was conspiratorial compared with only 5\% of NRO. Thus Parker and Barreto maintained TPM activists were much closer to reactionary conservatives than mainstream conservatives and that their findings supported the research of other scholars who found TPM activists are professing things that many Americans find difficult to believe.

Part of the conspiratorial argument is associated with the "birthers" who maintain that Obama is a Muslim born in Kenya. In the previously mentioned survey of 1580 persons, $41 \%$ of TPM supporters believed Obama was born in the US compared to $58 \%$ of all respondents. Many (23\% of the all those surveyed and $30 \%$ of the TPM supporters) did not know or did not answer the question (Zernike 2010).

An interview with Representative Bob Inglis (Republican, South Carolina) revealed the power of the TPM in South Carolina and its concerns about Bilderbergers. Inglis described part of a 2010 conversation with several TPM members as follows: "it turned into something about the Federal Reserve and the Bilderbergers and all that stuff. And now you have the feeling of antiSemitism here coming in, mixing in Wow" (Corn 2010). Also Inglis would not label Obama a socialist although he disagreed with Obama's policies. Inglis did not receive support from the Tea Partiers and lost the primary contest and no longer serves in the House of Representatives.

Devereaux (2012) reported that in 2012 both TPM and Occupy activists protested a Bilderberg conference in Chantilly Virginia. In addition the websites of various TPM groups provide information on the Bilderbergers and their meetings. For example, TeaParty.org reported that the June 2015 meeting of the highly secretive Bilderberg Group included the use of a hi-tech jamming system to protect their hotel from media coverage (2015a). TeaParty.org (2015b) believed that the Bilderbergers were developing currency restrictions including a "war on cash" that would likely be justified in order to stop the financing of terrorists like ISIS.

\section{Conclusion}

Both movements, though especially the TPM, have attempted to downplay racism, but several social scientists maintain its presence. We suggest that race, producerism, scapegoating and conspiracism provide bridging frames and thus fertile ground for at least some in these two movements to work together and 
possibly participate in both movements and recruit members. Elements of both movements seem to be interested in extending their appeal. Michael (2014:36)) suggests if the TPM isn't successful in "reaching out to minority populations" then "it could coalesce with the extreme right and be moved in a more radical direction". We suggest other scenarios are possible. The strongly racist and populist elements at the lower echelons of the TPM could turn to the WPM for support, especially if those at the highest echelons financed by the Koch brothers do little to relieve their middle class anxieties. WPM supporters could publically restrain their racism but profess their populist views and support the TPM. Both these have likely occurred. The question remains concerning how frequently those ideological bridges are being and will be crossed.

\section{References}

Barkun M (1997) Religion and the racist right. Chapel Hill: The University of North Carolina Press.

Barkun M (2003) A Culture of conspiracy. Berkeley: University of California.

Berbrier M (1998) "Half the battle": Cultural resonance, framing processes, and ethnic affectations in contemporary white separatist rhetoric. Social Problems 45: 431450.

Berbrier M (2000) The victim ideology of white supremacists and white separatists in the United States. Sociological Focus 33: 175-191.

Berlet C (2012a) Reframing populist resentments in the Tea Party Movement. In Steep, L Rosenthal, C Trost (Eds), 47-66. Berkeley: University of California.

Berlet C (2012b) Collectivists, communists, labor bosses, and treason. Critical Sociology 38(4): 565-587.

Berlet C, Lyons M (2000) Right-Wing Populism in America. New York: Guilford.

Burke M (2015) Race, gender, and class in the Tea Party. Princeton: Princeton University.

Canovan M (1999) Trust the People!. Political Studies XLVII: 2-16.

Corn D (2010) Confessions of a Tea Party causality. Mother Jones. Retrieved from bit.ly/1SDzb22. [Accessed 25 May 2015].

Devereaux R (2012 June, 2) Tea Party and Occupy activists rub shoulders at Bilderberg protest. The Guardian. Retrieved from bit.ly/23SkhbF. [Accessed 3 February 2016].

Dobratz B, Shanks-Meile S (1997) "White power, white pride!" The white separatist movement in the United States. NY: Twayne.

Hewitt C (2014) Terrorism and extremism in the United States. In Extremism in America, George Michael (Ed). Gainesville: University Press of Florida, 294-310.

Kaplan J (ed.). 2000. Encyclopedia of white power. Walnut Creek, CA: Alta Mira.

Kazin M (1998) The Populist Persuasion. Ithaca: Cornell University.

Kull S (2010) Big government is not the issue. Politico. Retrieved from politi.co/1TNEISI. [Accessed 18 June 2015].

Leicht K, Fitzgerald S (2014) Middle Class Meltdown. New York: Routledge.

Michael G (2014) The Tea Party and the far right. In Extremism in America, G Michael (Ed), 15-44. Gainesville: University Press of Florida.

Parker C, Barreto M (2013) Change they can't believe in. Princeton: Princeton University. 
Scher A, Berlet C (2014) The Tea Party Movement. In Understanding the Tea Party Movement, N Van Dyke, D Meyer (Ed), 99-123. Surrey, England: Ashgate.

Skocpol T, Williamson V (2012) The Tea Party and the remaking of Republican Conservatism. New York: Oxford.

Simi P, Futrell R (2010) American Swastika. Lanham, MD: Rowman \& Littlefield.

Snow D, Burke Rochford E Jr, Worden S, Benford R (1986) Frame alignment processes, micromobilization, and movement participation. American Sociological Review 51(4): 464-81.

Street P, DiMaggio A (2011) Crashing the Tea Party. Boulder: Paradigm.

TPM.org (2015a) Bilderberg deploys hi-tech jamming to shut down communications. Retrieved from bit.ly/1UXqehA. [Accessed 19 June 2015].

TPM.org (2015b) Secret War on Cash: Discussions at Bilderberg centered around capital controls, abolition of cash. Retrieved from bit.ly/1SDAU7t. [Accessed 20 June 2015].

Zernike K (2010) Boiling Mad. New York: Henry Holt. 
